\title{
Discrimination between different E-box-binding proteins at an endogenous target gene of c-myc
}

\author{
Laurie Desbarats, ${ }^{1}$ Stefan Gaubatz, and Martin Eilers \\ Zentrum für Molekulare Biologie der Universität Heidelberg (ZMBH), 69120 Heidelberg, Germany
}

\begin{abstract}
c-myc plays a key role in regulating mammalian cell proliferation and apoptosis. The gene codes for a transcription factor, Myc, that belongs to the helix-loop-helix/leucine zipper (HLH/LZ) family of proteins. Myc heterodimerizes with a partner protein termed Max; the heterodimeric complex binds to CAC(G/A)TG (E-box) sequences and activates transcription from these sites. However, several other HLH/LZ proteins, including USF and TFE-3, bind to and trans-activate from the same element, yet have no documented effect on cell proliferation or apoptosis. Therefore, it is likely that mechanisms exist that discriminate between these proteins for activation of natural target genes of Myc. We now show that trans-activation from the E-box in the rat prothymosin- $\alpha$ intron enhancer is indeed specific for Myc, and identify both the distance from the start site of transcription and a second E-box element adjacent to that recognized by Myc as critical determinants of specificity. Surprisingly, transcription activation domains required for Myc to activate from this distal enhancer position differ from previously mapped domains and closely correlate with those domains essential for transformation. As observed in transformation assays, Myc and Max strongly synergize in activation from a distal enhancer position. Our data suggest that trans-activation from the prothymosin intron enhancer is a faithful reflection of the transforming properties of the Myc protein.
\end{abstract}

[Key Words: Myc; USF; TFE-3; Max; prothymosin- $\alpha$ ]

Received September 8, 1995; accepted in revised version January 5, 1996.

c-myc was discovered as the cellular homolog of the transforming oncogene of a group of avian retroviruses that includes MC29, OK10, MH2, and FH3 (Alitalo et al. 1983; Colby et al. 1983; Watson et al. 1983). c-myc encodes a nuclear protein, $\mathrm{Myc}$, that acts as a key regulator of mammalian cell proliferation and apoptosis. This notion is supported by a large body of evidence demonstrating that expression levels of $c-m y c$ often correlate with cell proliferation and apoptosis, and that manipulation of c-myc function strongly affects both processes in a large number of experimental systems (for review, see Amati and Land 1994).

Myc is a transcription factor of the helix-loop-helix/ leucine zipper (HLH/LZ) family of proteins (Landschulz et al. 1988; Murre et al. 1989|. Similar to other members of this family, it binds to specific DNA sequences with a central CAC/G/A)TG element (Blackwell et al. 1990; Kerkhoff et al. 1991; Prendergast and Ziff 1991). Although Myc can bind to this sequence by itself, its affinity for DNA is greatly enhanced by heterodimerization with a second protein termed Max (Blackwood and Eisenman 1991; Prendergast et al. 1991). The heterodimeric complex acts as an activator of transcription (Amati et al. 1992; Kretzner et al. 1992; Amin et al.

\footnotetext{
${ }^{1}$ Corresponding author.
}

1993). Cell transformation, induction of cell proliferation, and induction of apoptosis by Myc all require heterodimerization with Max, strongly suggesting that trans-activation from E-box elements is critical for biological activities of Myc (Amati et al. 1993a,b). Other proteins [termed Mad-1, Mad-2(=Mxi-1),Mad-3, and Mad-4] have been identified that heterodimerize with Max, but not Myc, and that often accumulate in quiescent cells (Ayer et al. 1993; Zervos et al. 1993; Hurlin et al. 1995). Heterodimeric complexes containing Max and either Mad or Mxi are active repressors of transcription through binding of a protein termed $\sin 3$ (Ayer et al. 1995; Schreiber-Agus et al. 1995). Taken together, the data suggest strongly that Myc, Max, and Mad proteins form a network of interacting proteins that controls a set of target genes critically involved in apoptosis and proliferation by binding to E-box elements in the regulatory elements of these genes (for review, see Amati and Land 1994).

However, several other transcription factors have biochemical properties very similar to Myc/Max heterodimers. These include ubiquitous cellular factor (USF) and transcription factor E3 (TFE-3), two HLH/LZ proteins identified through their binding to E-box elements in the adenovirus major late promoter and the $\operatorname{IgH}$ enhancer, respectively (Beckmann et al. 1990; Gregor et 
al. 1990|. Both recognize DNA sequences identical to those bound by Myc/Max heterodimers, and both USF and TFE- 3 have been shown to be potent activators of transcription (Chodosh et al. 1986; Beckmann et al. 1990). Indeed, in many cells, USF is by far the most abundant protein binding to CACGTG elements as judged by gel shift experiments with nuclear extracts. In such experiments, only very small amounts of $\mathrm{Myc} / \mathrm{Max}$ complexes are detectable, even from cells that are transformed by c-myc (Littlewood et al. 1992). Yet, in the absence of deregulated c-myc, cells maintain normal growth control and show no signs of apoptosis. How then can a small amount of Myc protein transform cells if significant amounts of proteins with similar DNAbinding properties are already present in a cell?

Several possibilities exist to explain this paradox. First, Myc has been reported to also act as a repressor of transcription and this may be more relevant for transformation than its transcriptional activation functions (Roy et al. 1993; Li et al. 1994). Second, the aminoterminus of Myc has been shown to bind to $\mathrm{p} 107$, a pocket protein that negatively regulates cell proliferation (Beijersbergen et al. 1994; Gu et al. 1994). Similar to models proposed for nuclear oncogenes of DNA tumor viruses, sequestering p107 may be critical for cell transformation by Myc. And third, assays using synthetic reporter constructs with multimerized binding sites may give misleading results. Indeed, mechanisms discriminating between closely related members of a family of transcription factors often involve interactions with proteins binding to adjacent elements and such interactions would be missing in synthetic reporter constructs (Diamond et al. 1990; Cleary et al. 1993; Genetta et al. 1994; Weintraub et al. 1994).

Previous work has shown that the rat gene encoding prothymosin- $\alpha$ fulfills the criteria for a bona fide target gene of c-myc. This is supported by the following findings: (1) Activation of conditional alleles of Myc (MycER; Eilers et al. 1989) in confluent rat fibroblasts activates transcription of prothymosin- $\alpha$ rapidly; preincubation of cells with cycloheximide does not block transcriptional activation by $\mathrm{Myc}$, demonstrating that no intermediate protein has to be synthesized to mediate this effect (Eilers et al. 1991). Rapid activation of prothymosin- $\alpha$ expression is also observed in both mouse and human cells expressing either $\mathrm{c}-\mathrm{Myc}$ or $\mathrm{N}-\mathrm{Myc}$ under the control of Zinc-regulatable or tetracycline-regulatable promoters (Tavtigian et al. 1994; A. Pollack, pers. comm.; W. Lutz and M. Schwab, pers. comm.). (2) An E-box element has been identified in the first intron of the gene, to which Myc/Max complexes bind with high affinity and can be trans-activated by Myc in transient transfection assays (Gaubatz et al. 1994). (3) Reintegration of reporter plasmids carrying this sequence into MycER cells shows that Myc can activate transcription specifically from this element in vivo (Gaubatz et al. 1994).

We now show that trans-activation from the E-box in the first intron of the prothymosin- $\alpha$ gene is specific for Myc and identify two distinct mechanisms that determine specificity. Further, we show that trans-activation by Myc from this site differs significantly from that observed in previously described trans-activation assays and closely reflects transforming properties of the protein.

\section{Results}

Activation of the rat prothymosin- $\alpha$ gene by Myc is mediated by a response element located $1.6 \mathrm{~kb}$ downstream of the start site of transcription in the first intron of the gene (Gaubatz et al. 1994). Initial experiments had suggested that a reporter construct containing 36 bp surrounding this site in front of a tk81 minimal promoter was activated both by USF and by Myc in transient transfection assays (see below).

To test whether trans-activation might be specific for Myc if the E-box element was kept at its normal position within the gene, a reporter plasmid was constructed that retained $250 \mathrm{bp}$ of the prothymosin- $\alpha$ promoter, exon I, intron I, and part of exon II (PrT-CAT; Fig. 1A). Translation of the mRNA transcribed from this reporter yields a fusion protein containing the first 24 amino acids of prothymosin- $\alpha$, a 36-amino-acid linker region, and chloramphenicol acetyltransferase (CAT). As a control, the single CACGTG element present in this construct was disrupted by insertion of an oligonucleotide containing two binding sites for the yeast transcription factor GAL4 (Kakidani and Ptashne 1988), yielding GALmE-PrT-CAT (Fig. 1A). Both constructs were transfected transiently into HeLa cells either alone or together with expression plasmids encoding Myc, USF, or TFE-3 proteins, respectively. Expression of Myc activated specifically the prothymosin- $\alpha$ reporter (PrT-CAT), but not the derivative carrying a mutated E-box (GALmE-PrT-CAT). Ectopic expression of USF also activated PrT-CAT; however, USF equally trans-activated GALmE-PrT-CAT, demonstrating that activation did not occur through the E-box element. Similarly, activation by USF has been reported for a number of other promoters lacking an E-box and may reflect interactions occurring at or near the start site of transcription (Du et al. 1993; Li et al. 1994). Ectopic expression of TFE-3 did not affect significantly either the wild-type or the mutant reporter. As a control, we showed that all three proteins activated a synthetic reporter plasmid carrying multiple E-boxes in front of an SV40 minimal promoter in an E-box-dependent manner (Fig. 1B). We concluded that activation through the E-box in the intron of the prothymosin- $\alpha$ gene is specific for Myc. Subsequent experiments also showed that transactivation by Myc/Max complexes (see below) occurred through this element.

To determine why USF failed to activate through this element, we first assayed whether binding of USF to this sequence might occur with lower affinity than binding of Myc/Max complexes. ${ }^{32} \mathrm{P}$-labeled oligonucleotides, encompassing the prothymosin- $\alpha$ Myc-responsive element, were incubated either with USF, partially purified from HeLa cells, or with Myc/Max complexes reconstituted from recombinant proteins. Competition with unlabeled oligonucleotides was performed to gain an initial insight into the relative affinities of binding. In these experi- 
A

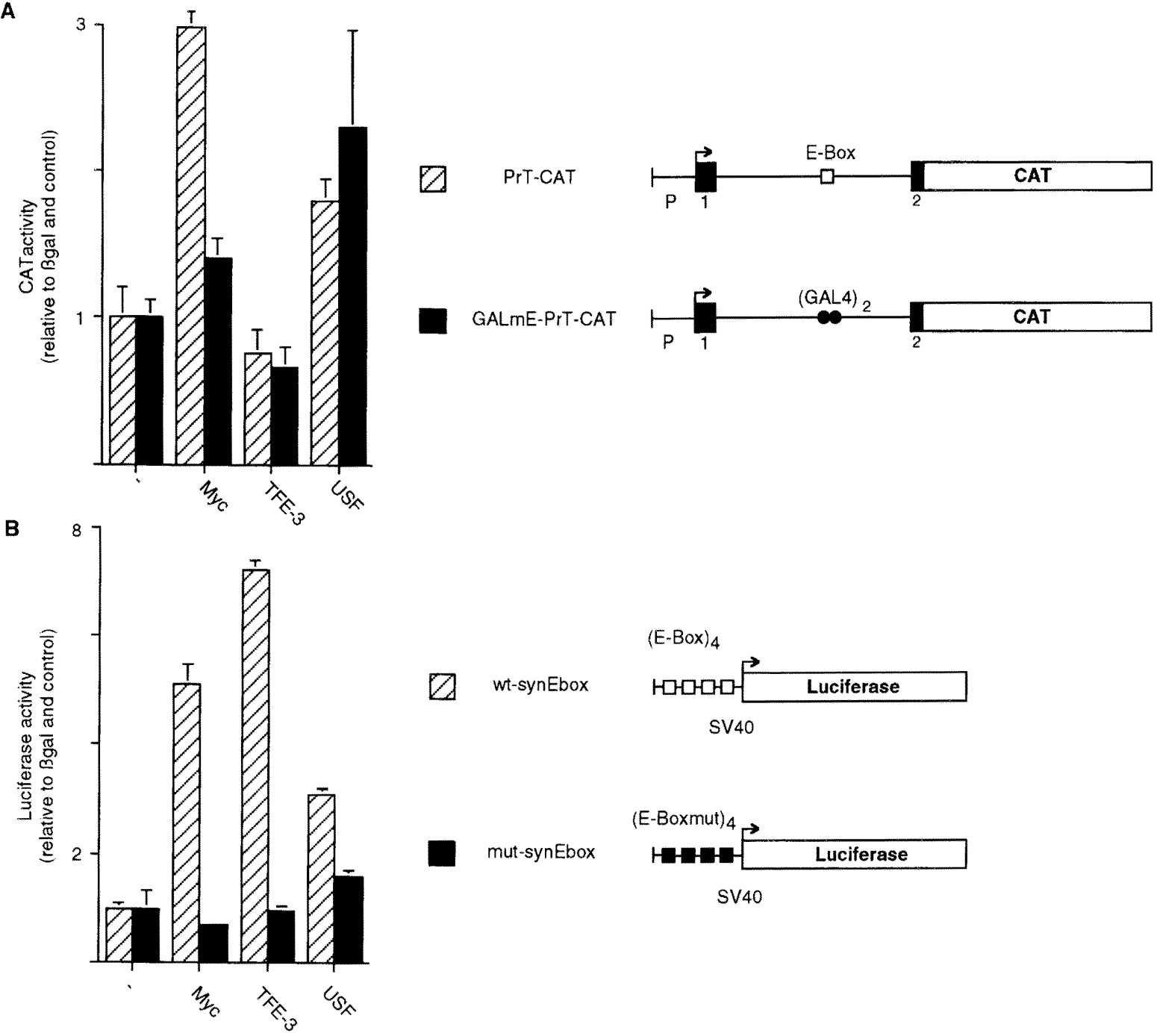

Figure 1. Myc, but not USF or TFE-3, specifically trans-activates a prothymosin- $\alpha$ reporter plasmid. $(A)$ Results from transient transfection experiments in HeLa cells with either a wild-type (hatched bars) or a mutated (solid bars) prothymosin reporter construct. The diagram at right depicts the structure of the reporter constructs used. $(\mathrm{P})$ prothymosin promoter; $(1$ and 2$)$ exons 1 and 2 , respectively; (E-Box) Myc-binding site in intron I (in PrT-CAT). In GALmE-PrT-CAT this site is disrupted by insertion of an oligonucleotide carrying two GAL 4-binding sites; otherwise, the two reporters are identical. $(B)$ Results from similar transfection assays using a synthetic reporter construct (depicted schematically on the right). Hatched bars represent results with four intact E-box elements; solid bars with a mutated derivative.

ments, USF, Myc/Max, and Max/Max complexes all specifically bound to the E-box and were competed by similar amounts of nonradioactive wild-type oligonucleotide (Fig. 2A). Next, we performed protein competition experiments in which we added either increasing amounts of USF to Myc/Max complexes prebound to limiting amounts of radiolabeled oligonucleotide or performed the reverse experiment. The results from these experiments showed that increasing amounts of USF displaced prebound Myc/Max complexes efficiently and vice versa (Fig. 2B; data not shown), further supporting the notion that the relative affinities of both complexes for DNA are comparable. In conclusion, we could not obtain any evidence that failure of USF to bind to this element or to compete with bound Myc/Max complexes was responsible for the inability of USF to activate from this site. In addition, USF has been shown to be the major protein bound to this site in nuclear extracts from rat fibroblasts (Gaubatz et al. 1995).

We wondered, therefore, whether trans-activation by USF bound at the E-box might be inefficient, and tested whether the trans-activation domain of USF was capable of activating from the position of the E-box in the prothymosin- $\alpha$ intron. Chimeric proteins were constructed in which the trans-activation domains of Myc and USF were fused to the DNA-binding domain of the yeast transcription factor GAL4 (Sadowski and Ptashne 1989). GAL4-Myc activated efficiently a reporter plasmid in 
A

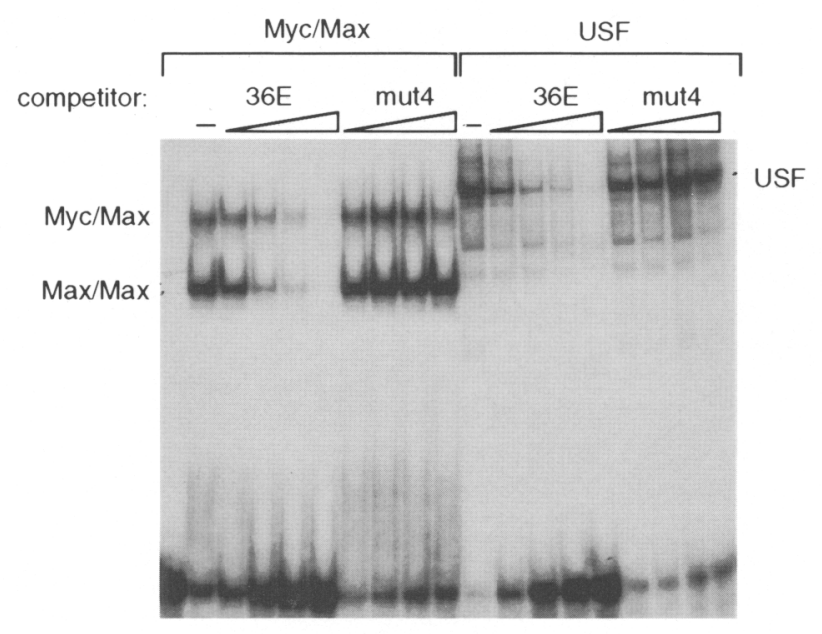

$36 \mathrm{E}$

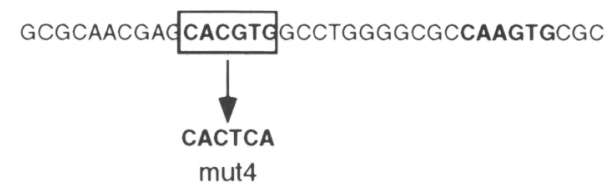

B

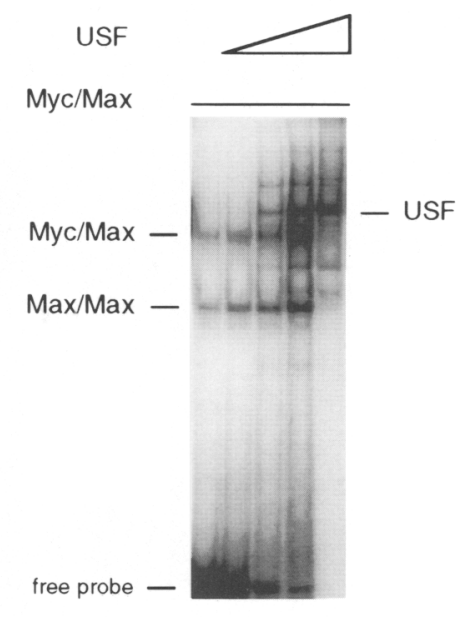

Figure 2. The relative affinity of USF for the prothymosin- $\alpha$ E-box is similar to that of Myc/Max and Max/Max complexes. $\{A \mid$ Gel-shift reactions containing radiolabeled 36E oligonucleotide (Gaubatz et al. 1995) and either recombinant Myc and Max proteins or USF partially purified from HeLa cells. Competitions contained either $0,1,5,10$, or 50 ng of unlabeled wild-type or mut4 oligonucleotide. $(B)$ Preassembled Myc/Max complexes were incubated with 36E oligonucleotide and then challenged with increasing amounts of USF under conditions in which the amount of probe was limiting. The positions of the individual complexes (as determined by gel-shift reactions with individual components and supershifting with specific antibodies; not shown; Gaubatz et al. 1995) are shown at the sides of the autoradiograph.

which two GAL4-binding sites were introduced at the site of the prothymosin- $\alpha$ E-box, but not a reporter lacking GAL4-binding sites (Fig. 3A). In contrast, GAL4-USF activated both constructs poorly and no specific activation through the GAL4-binding site was detectable. We concluded that the trans-activation domain of USF, in contrast to that of Myc failed to activate from the prothymosin- $\alpha$ intron position.

A series of deletion constructs of the prothymosin- $\alpha$ gene was used to identify elements that potentially might interfere with trans-activation by USF (Fig. 3B). Exchange of the prothymosin- $\alpha$ promoter against the thymidine kinase 81 (tk81) minimal promoter did not restore activation by USF, suggesting that the inability to activate was not attributable to interactions occurring at the start site of transcription. In contrast, all reporter plasmids in which the distance between the E-box and the start site of transcription was $<400 \mathrm{bp}$ were transactivated efficiently by USF in a site-specific manner (Fig. 3B). This suggested that in these constructs, either a repressor element had been lost that discriminated against USF or that the distance between the E-box and the start site of transcription by itself was a critical determinant of specificity.

To test whether distance might be the critical factor discriminating between USF and Myc, we made use of a reporter in which multiple GAL4-binding sites were placed $2 \mathrm{~kb}$ downstream of the start site of transcription (pCL- $8 \times 17$; Fig. $3 \mathrm{C}$ ). In this construct, a chicken lysozyme promoter drives a luciferase reporter gene and no elements from the prothymosin- $\alpha$ gene are present (Annweiler et al. 1994). Expression of GAL4-Myc efficiently activated this construct; in contrast, GAL4-USF was completely inefficient in activation from this distal position. Both GAL4-Myc and GAL4-USF activated a reporter with multiple GAL4 sites immediately adjacent to a minimal TATA element with similar efficiency $\left(17 \mathrm{~m}_{2}\right.$-TATA-LUC; Fig. 3C $)$. Although we cannot exclude that other factors might contribute to the discrimination between USF and Myc, we conclude that the distance between the E-box element and the start site of transcription is alone sufficient to account for the different trans-activation properties of the two proteins.

Similar experiments failed to reveal significant differences between the trans-activation domains of TFE-3 and Myc. In particular, GAL4-TFE-3 specifically activated a reporter plasmid in which GAL4-binding sites were placed at the position of the prothymosin- $\alpha$ E-box, but not a derivative lacking GAL4 binding sites (Fig. 3A). This observation strongly suggests that distance from the start site of transcription is not a major factor discriminating against trans-activation by TFE-3. In addition, TFE- 3 has been shown previously to activate from an IgH subfragment placed $3^{\prime}$ to a $\beta$-globin-CAT re- 
A

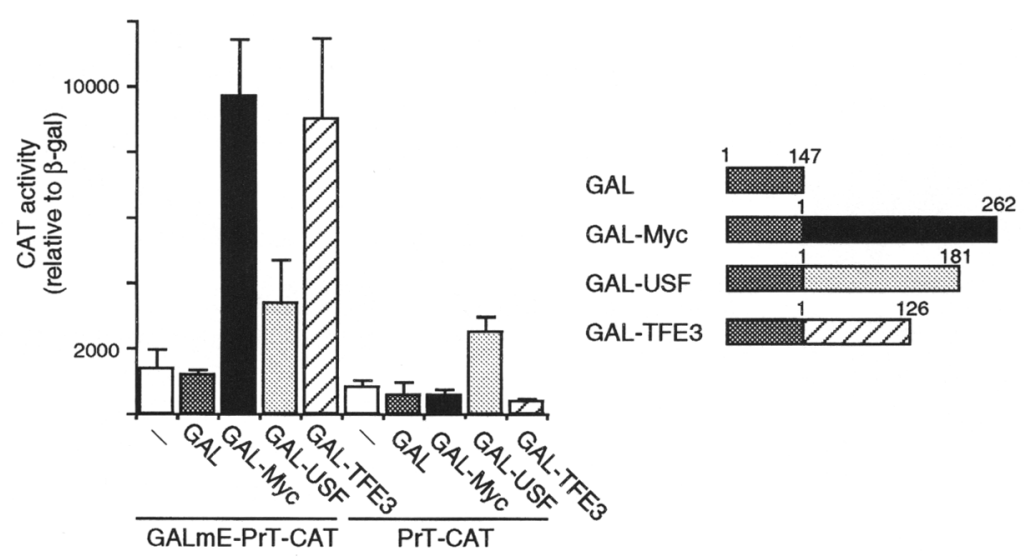

B
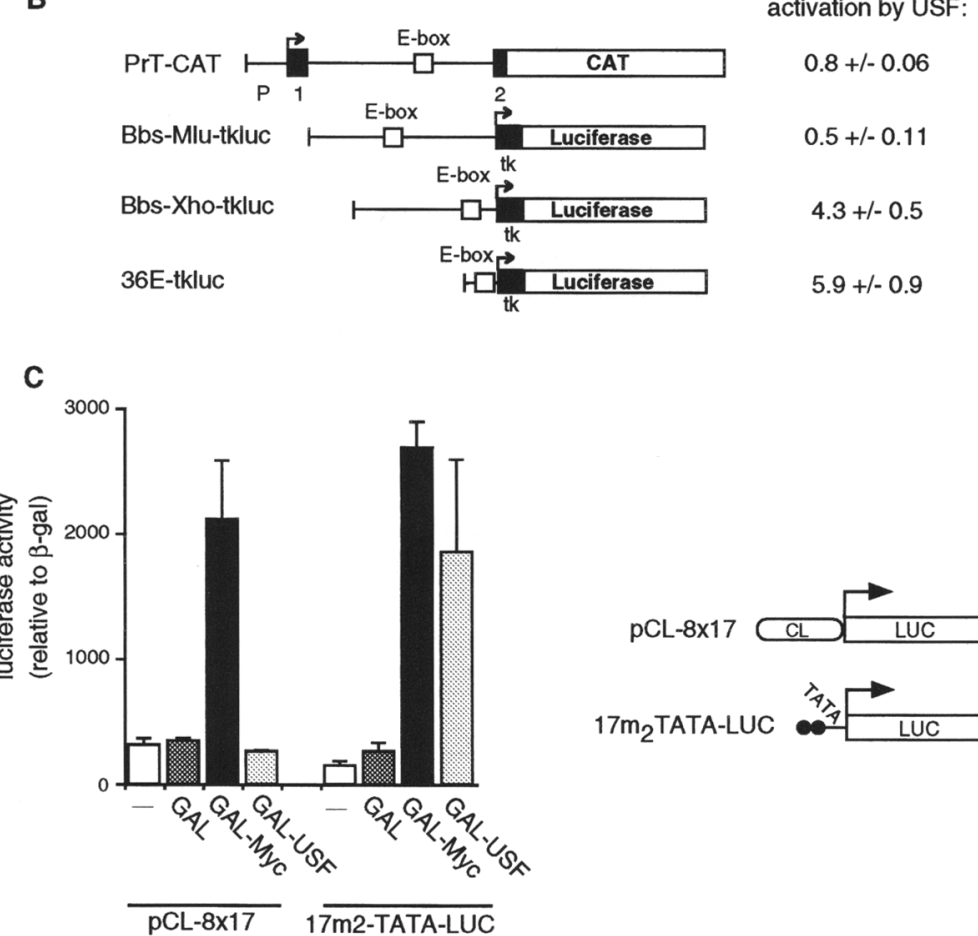

Figure 3. USF does not activate from a distal enhancer position. $(A)$ The trans-activation domain of USF fails to activate from the position of the E-box in the prothymosin- $\alpha$ intron. Chimeric proteins were constructed that carry the trans-activation domains of either USF, TFE-3 of Myc fused to the DNA-binding domain of the yeast transcription factor GAL4. The constructs are depicted at right; the numbers indicate the amino acids of each protein present in the chimera. As reporters, either GALmE-PrT-CAT or, as a control, PrT-CAT were used (see Fig. 1A). (B) The position of the E-box affects its inducibility by USF. Shown are the results of transactivation assays with USF and different prothymosin reporter plasmids. For each construct, a derivative with a disrupted E-box was constructed. Fold E-box specific activation was calculated by dividing the fold activation on a wild-type by that on a mutated construct. We chose this strategy because USF activated a number of reporters in an E-box independent manner to varying degrees. $|C|$ The trans-activation domain of USF activates from a proximal, but not a distal, binding site. Shown are results from transient transfection assays using either GAL-USF or GAL-Myc as effectors. As reporters, we used two plasmids that carry GAL4-binding sites either immediately adjacent to a minimal TATA element or downstream of a luciferase gene driven by a minimal chicken lysozyme (CL) promoter (Annweiler et al. 1994); the constructs are depicted on the right. porter, demonstrating that TFE-3 is capable of activating from an enhancer position far away from the start site of transcription (Beckmann et al. 1990). Further, gel-shift experiments with recombinant TFE-3 demonstrated that TFE-3 bound specifically to the prothymosin- $\alpha$ E-box with a relative affinity similar to that of USF and $\mathrm{Myc} /$ $\operatorname{Max}$ (Fig. 4A).

Previously, the failure of TFE-3 to activate the $\operatorname{IgH}$ enhancer in non-B cells (and also of MyoD to activate the IgH enhancer) has been attributed to the presence of an E-box element ( $\mu \mathrm{E} 5$ site) that binds a repressor protein that inhibits trans-activation by TFE-3 (or MyoD) (Genetta et al. 1994; Weintraub et al. 1994). Mutation at or adjacent to the $\mu \mathrm{E} 5$ site abolishes binding of the repressor and allows trans-activation by TFE-3 or MyoD. We noted that a very similar element (CAAGTG instead of CAGGTG) is present at a comparable distance to the Myc-responsive E-box in the prothymosin- $\alpha$ intron enhancer (Fig. 4B) and therefore tested whether its presence interfered with trans-activation by TFE-3. In contrast to both USF and Myc, TFE-3 failed to activate a reporter construct in which $36 \mathrm{bp}$ of sequence surrounding the prothymosin- $\alpha$ E-box (and also containing the second $\mu E 5$-like E-box) are cloned in front of a tk8 1 minimal promoter (36E-tkLUC; Fig. 4B). Significantly, mutation of the GTG in the second, $\mu$ E5-like E-box (mut1 and del1) allowed trans-activation by TFE-3. In contrast, several mutations surrounding the GTG had no effect (Fig. 4B). We also noted a marked increase in basal activity of the mut 1 construct (from 2 - to 10 -fold) compared to the 


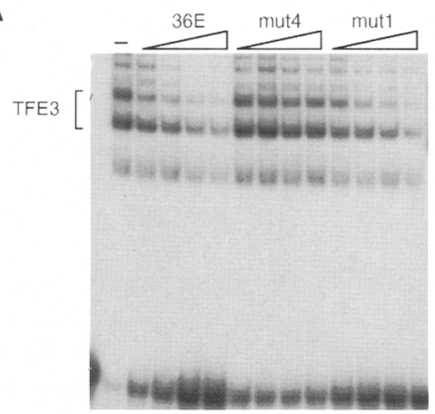

B

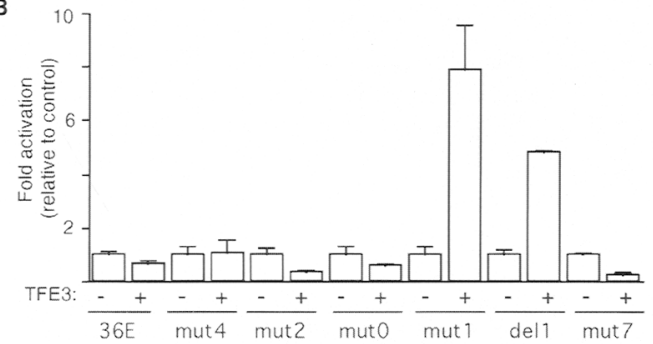

36 GCGCAACGAGCACGTGGCCTGGGGCGCCAAGTGCGC

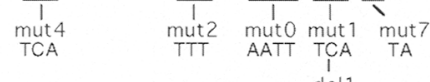

c
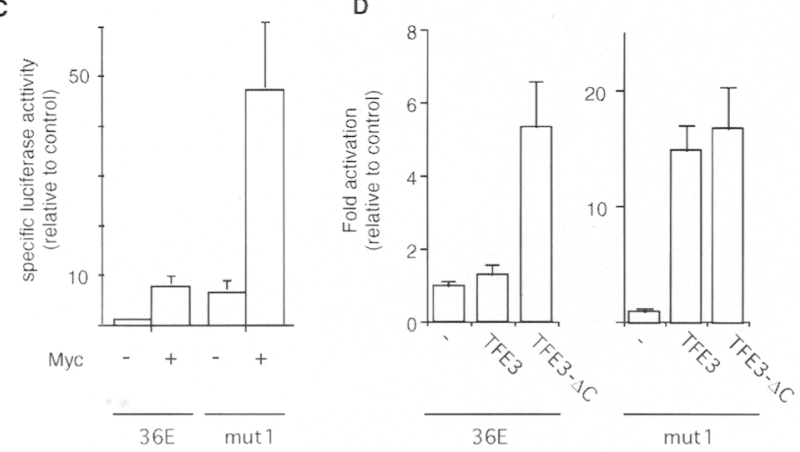

Figure 4. A second E-box element discriminates against transactivation by TFE-3, but not Myc. $(A)$ Recombinant TFE- 3 binds specifically to the CACGTG element in the prothymosin- $\alpha$ intron. Shown are gel-shift reactions with radioactive $36 \mathrm{E}$ oligonucleotide and recombinant TFE-3 purified from Escherichia coli. The sequence of the competitors is shown in $B$; the amounts used are identical to those in Fig. 2. (B) Shown are the results of transient transfection experiments with CMV-TFE-3 and different reporter constructs; the sequences of the oligonucleotides in the reporters are given below. $(C)$ Shown are results from similar transient transfection assays with $\mathrm{Myc}$ and the 36E-tkLUC (36E) and mut1-tkLUC (mutl) reporters. (D) The target of repression is the carboxyl terminus of TFE-3. Transient transfections contained CMV-TFE- 3 or CMV-TFE- $3-\Delta C$ on the indicated reporters.

wild-type reporter (not shown). This suggested that additional endogenous factors gained access to the prothymosin- $\alpha$ E-box by this mutation. Mutation at this site (mut1) did not affect trans-activation by Myc (Fig. 4C), nor did it affect binding of TFE-3 to the Myc-responsive E-box (Fig. 4A).
We concluded that the presence of a second E-box element discriminates against trans-activation by TFE-3. Because trans-activation by GAL4-TFE-3 was not inhibited in the prothymosin- $\alpha$ reporter containing GAL4binding sites (Fig. 3A), we reasoned that the target of repression in TFE-3 is either the DNA binding/dimerization domain or the carboxyl terminus of the protein. To test the latter hypothesis, we constructed an allele of TFE- 3 that lacked the carboxyl terminus of the protein. In contrast to TFE-3, TFE-3- $\Delta$ C was clearly capable of activating the wild-type (36E-tkLUC) reporter; both TFE- 3 and TFE-3- $\Delta C$ activated the mut 1 reporter construct with similar efficiency (Fig. 4D). Also, deletion of the carboxyl terminus has been shown to diminish activation of a synthetic reporter construct by TFE-3 (Artandi et al. 1995). Thus, we conclude that the target of repression is the carboxyl terminus of TFE-3; interestingly, several other E-box-binding proteins contain a conserved carboxyl terminus, suggesting that they might be repressed in a similar way (Artandi et al. 1995). However, the precise mechanism by which proteins binding at this site affect trans-activation by TFE- 3 remains to be determined.

To provide independent confirmation that prothymosin- $\alpha$ is activated specifically only by Myc, and not by other endogenous E-box-binding proteins, we made use of the finding that expression of a Myc protein with a mutant DNA-binding region (MycmutBR) activates a reporter construct with synthetic E-boxes (Kretzner et al. 1992). Such a protein will sequester Max into non-DNAbinding heterodimers, and therefore block both activation by Myc/Max and repression by Max/Max complexes. It has been proposed that trans-activation of synthetic E-box reporters by MycmutBR stems from the fact that sequestering Max enables other endogenous proteins to gain access to, and activate from, the E-box (Fig. 5A). Thus, activation should not occur if an E-box is only activated by Myc/Max complexes (which would be competed for by MycmutBR), but not by other E-box-binding proteins.

Therefore, we transfected appropriate reporter constructs into HeLa cells together with an expression plasmid encoding MycmutBR (Fig. 5B). Similar to published observations, MycmutBR activated a reporter construct in which the E-box was placed close to the tk81 minimal promoter; activation occurred through the E-box as a reporter with a triple point mutation in the E-box was not trans-activated. A mutant of Myc that does not bind $\operatorname{Max}, M y c \Delta L Z$, did not activate the proximal promoter. Similar results were obtained with reporters containing concatemerized synthetic E-boxes (data not shown). In contrast, expression of MycmutBR did not activate the prothymosin- $\alpha$ reporter with the E-box in its normal intron position (PrT-CAT). These data show that endogenous proteins, like USF, that do not heterodimerize with Max, fail to activate transcription through the E-box in the prothymosin- $\alpha$ intron.

The previous results showed that the difference in trans-activating domains is a critical determinant of specificity between USF and Myc. We speculated, there- 
A
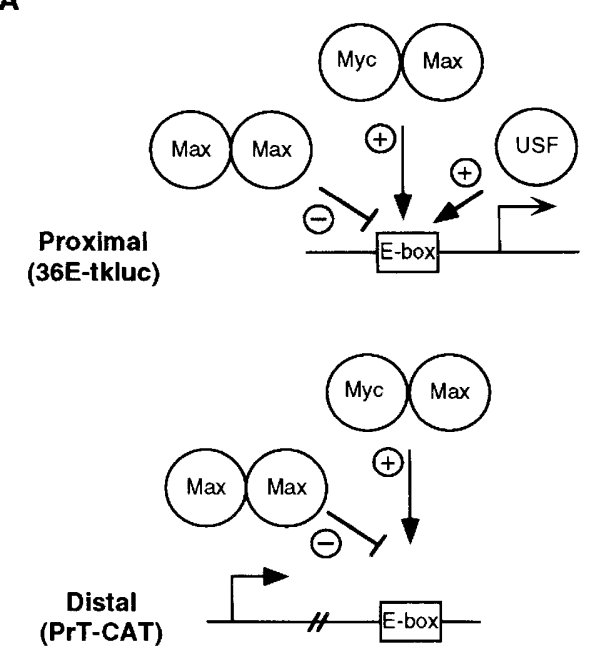
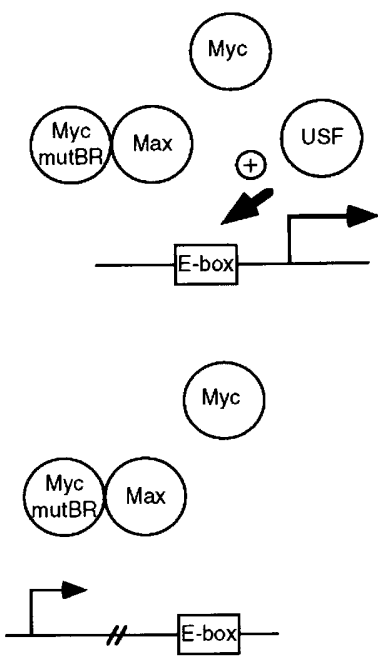

B

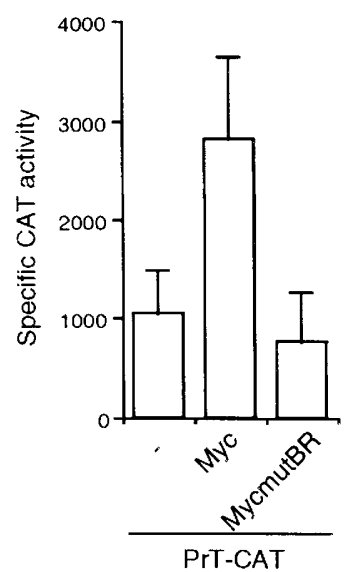

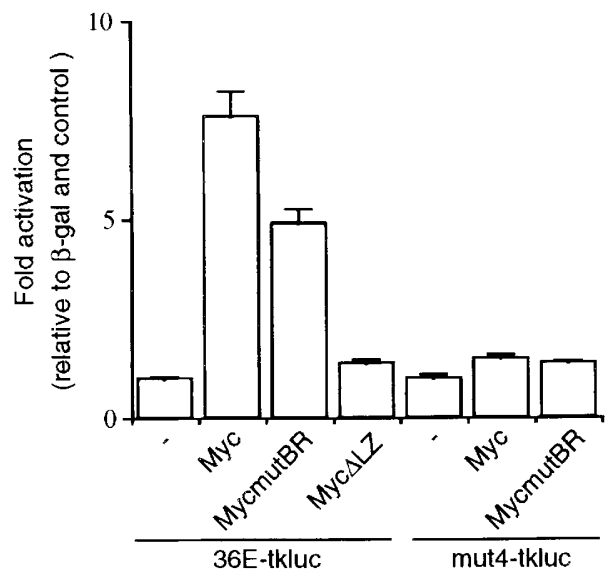

Figure 5. Myc proteins mutated in the basic region activate from a proximal, but not a distal, position. $(A)$ Rationale of the experiment. Myc protein mutated in the basic region (MycmutBR) is expected to sequester Max into non-DNA-binding complexes and enhance access of other transcription factors. If those are capable of binding and trans-activation, expression of MycmutBR results in trans-activation of the reporter. $(B)$ Results from transient transfection experiments with reporter plasmids carrying an E-box either in a distal (PrT-CAT) or a proximal (36EtkLUC) position, or an E-box mutation (mut4-tkLUC). fore, that the trans-activation domains used by Myc from a distal enhancer position might differ from those mapped with reporter plasmids that contain E-box elements in promoter-proximal positions. Thus, we assayed a number of previously characterized mutant alleles of Myc for trans-activation of proximal and distal reporters in parallel (Stone et al. 1987; Philipp et al. 1994). To exclude variations between different experiments, we made use of the fact that one reporter drives expression of CAT, the other of luciferase, and transfected both reporters into the same cells (Fig. 6A). Expression of wildtype Myc led to a three-fold activation of both reporter plasmids. Results with the proximal reporter largely confirmed our own previous results obtained in CV-1 cells and agreed with numerous results obtained by other workers (Gaubatz et al. 1994). The data show that small mutations or insertions in the amino terminus of Myc did not affect trans-activation significantly from a promoter-proximal site. In particular, mutations in either Myc box I or Myc box II, two highly conserved elements in the amino terminus of the protein, did not impair trans-activation by Myc. In contrast, mutation in either element abolished trans-activation by Myc from a distal enhancer element, whereas other mutations had smaller effects (Fig. 6A). Mutations in Myc box I and Myc box II were not equivalent, however, because mutations in Myc box II often acted as dominant-negative alleles when transfected at high concentrations (Fig. 6A; data not shown). Such behavior was not observed for mutations in Myc box I.

We extended these observations by making use of constructs with point mutations in Myc box II of murine Myc. Cole and co-workers have shown that mutation of a tryptophan residue at position 136 abolishes the ability of murine Myc to transform rat embryo fibroblasts in cooperation with an activated allele of ras (Brough et al. 1995). Data presented in Figure 6B show that this mutation also significantly impaired the ability of Myc to activate from a distal position, whereas it did not affect activation by Myc from a proximal-promoter position. Point mutations at positions 58 and 62 did not impair trans-activation by Myc in this assay (not shown).

Because wild-type and mutant alleles of Myc behaved differently on the proximal and distal reporter plasmids, 
Desbarats et al.
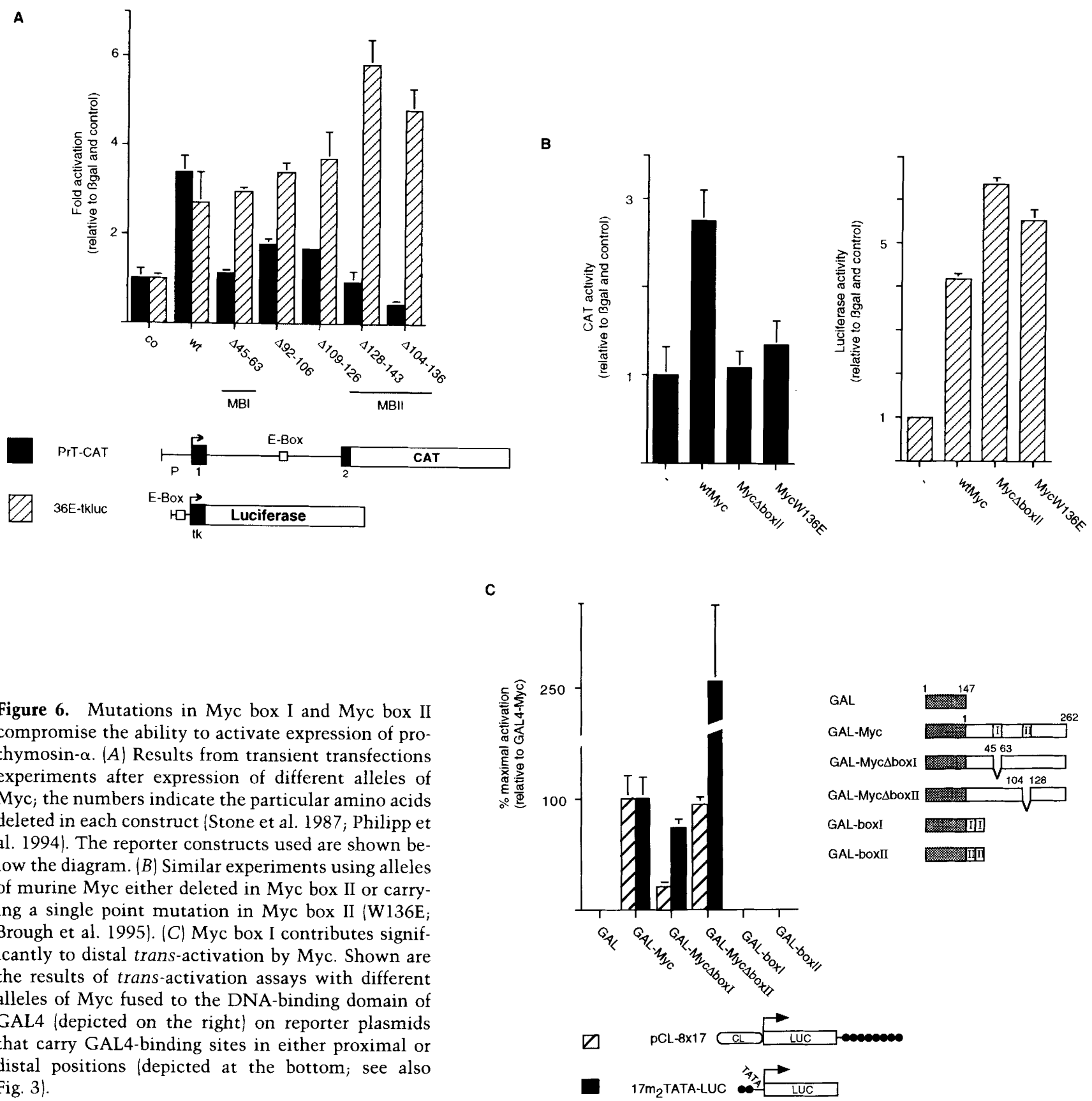

Figure 6. Mutations in Myc box I and Myc box II compromise the ability to activate expression of prothymosin- $\alpha .(A)$ Results from transient transfections experiments after expression of different alleles of Myc; the numbers indicate the particular amino acids deleted in each construct /Stone et al. 1987; Philipp et al. 1994). The reporter constructs used are shown below the diagram. (B) Similar experiments using alleles of murine Myc either deleted in Myc box II or carrying a single point mutation in Myc box II (W136E; Brough et al. 1995). (C) Myc box I contributes significantly to distal trans-activation by Myc. Shown are the results of trans-activation assays with different alleles of Myc fused to the DNA-binding domain of GAL4 (depicted on the right) on reporter plasmids that carry GAL4-binding sites in either proximal or distal positions (depicted at the bottom; see also Fig. 3).

we made use of a series of deletion constructs of the prothymosin- $\alpha$ gene (see Fig. 3B) to identify which regions of the gene might be important for these differences. Similar to observations made for trans-activation by USF (Fig. 3B), the distance between the E-box and the start of transcription appeared to determine whether the different alleles of Myc caused trans-activation (data not shown). However, we cannot exclude the presence of specific sequence determinants that inhibited trans-activation by mutant alleles of Myc.

To gain some insight into what roles Myc box I and Myc box II might play in trans-activation from a distal enhancer position, we constructed several fusion proteins in which the amino terminus of different alleles of Myc (amino acids 1-262 of wild-type or mutant Myc) were fused to the DNA-binding domain of GAL4. In addition, sequences of either Myc box I or Myc box II were multimerized and fused to GAL4. These experiments revealed that neither Myc box I nor Myc box II (as GAL4 chimeras) had significant trans-activation ability by itself, either from a proximal or a distal position (Fig. 6C). Deletion of Myc box I impaired trans-activation significantly from a distal, but only moderately impaired transactivation from a proximal position (Fig. 6C), suggesting 
that Myc box I provides an auxiliary function required to activate from a distal enhancer element. In contrast, deletion of Myc box II impaired neither trans-activation from a distal nor a proximal position in the context of a GAL4 chimera, suggesting that the deletion of the carboxyl terminus of Myc protein relieved the requirement for Myc box II. As the carboxyl terminus of Myc strongly represses trans-activation by the amino terminus (data not shown; Cziepluch et al. 1993; A. Zervos, pers. comm.), our data might suggest that Myc box II may be involved in the relief of this repression.

Finally, we decided to address the question of whether Myc and Max might synergize to activate expression of prothymosin- $\alpha$. Myc and Max have been reported to cooperate in cell transformation (Prendergast et al. 1992), but no or only low levels of synergy have been observed in transient trans-activation assays (Kretzner et al. 1992; Amin et al. 1993; Gaubatz et al. 1994; Lee et al. 1995). To address this issue, expression plasmids encoding Myc and Max were cotransfected into HeLa cells together with the prothymosin- $\alpha$ reporter plasmid. In these experiments, a strong synergy between Myc and Max was observed (Fig. 7A). Transfection of increasing amounts of Max led to a strong and continuous increase in transactivation by Myc alone from the distal, but not the proximal, reporter plasmid, suggesting that, similar to observations made for the trans-activation domains, synergy depended on the position of the E-box element (Fig. 7B). To extend these observations Myc was cotransfected with different alleles of Max, either wild-type or mutated in the leucine zipper or the DNA-binding region of the protein. In these experiments, different alleles of Max did not affect trans-activation significantly from a proximal position (not shown). In contrast, trans-activation from a distal position was completely abolished by MaxmutBR, and significantly impaired by Max $\Delta \mathrm{LZ}$ (Fig. 7C). In addition, Max showed no synergy when cotransfected with a Myc allele that carried a deletion in Myc box II (data not shown). Taken together, our data suggest strongly that an intact Myc/Max heterodimer is the only functional transcription factor that can activate the E-box in the intron of the rat prothymosin- $\alpha$ gene.

\section{Discussion}

Previous work has established that the Myc protein is a member of the HLH/LZ family of transcription factors and has left little doubt that its ability to regulate target genes via CACGTG elements is critical for its ability to induce cell transformation, cell cycle progression, and apoptosis (for review, see Amati and Land 1994). This model makes two predictions. First, that mechanisms exist on natural target genes of Myc that discriminate between Myc/Max complexes and closely related transcription factors with similar biochemical, but very different biological properties. Second, the model predicts that results from trans-activation assays should faithfully reflect those obtained in transformation assays.

Several distinct mechanisms that discriminate between closely related members of a family of transcription factors have been described. For the Fos/Jun family of transcription factors (Diamond et al. 1990), for Oct proteins (Lai et al. 1992; Cleary et al. 1993), and for members of the HLH family of transcription factors (Genetta
A

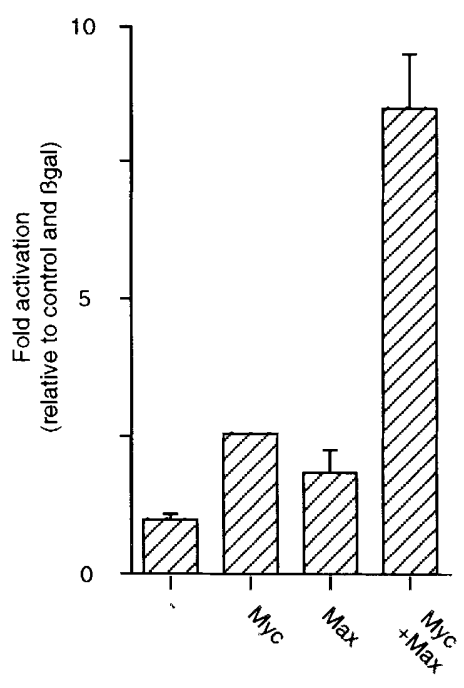

B

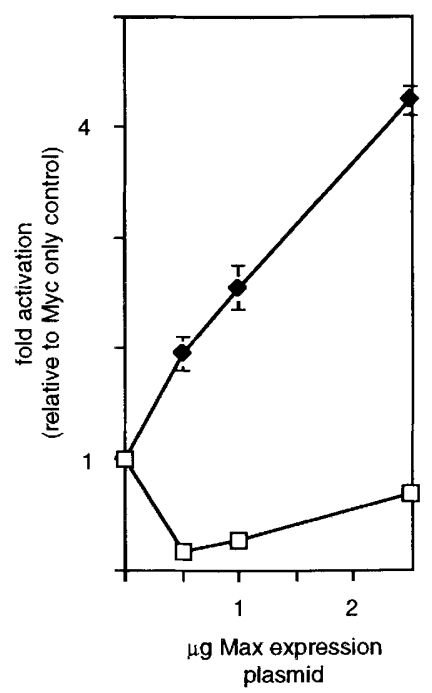

C

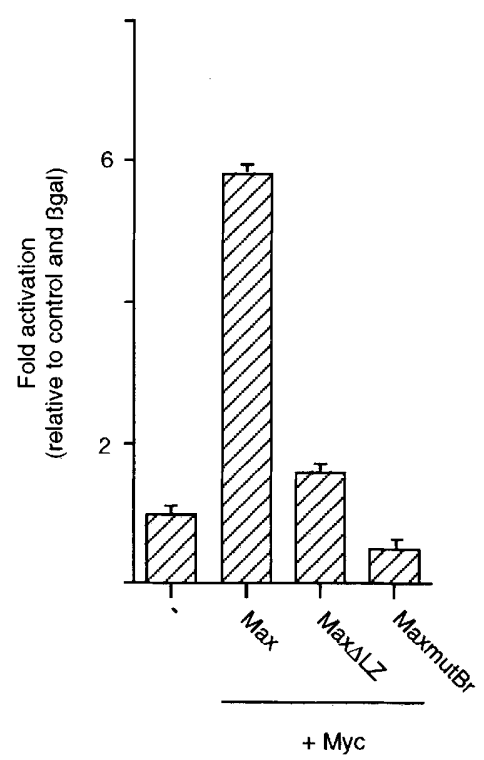

Figure 7. Myc and Max synergize to activate expression of prothymosin- $\alpha .(A, B)$ Results of transient trans-activation assays using either PrT-CAT $(A)$ or both PrT-CAT $(\downarrow)$ and 36E-tkLUC $(D)$ in parallel $(B)$. $(A)$ Results obtained with constant amounts $(1 \mu \mathrm{g})$ of effector plasmids; $(B)$ titration of Max expression plasmid in the presence of $1 \mu \mathrm{g}$ of CMV-Myc. $(C)$ mutations in the Max leucine zipper or the basic region strongly impair trans-activation by Myc. The experiment was carried out as before using PrT-CAT as reporter plasmid and $0.5 \mu \mathrm{g}$ of effector plasmids. 
et al. 1994; Weintraub et al. 1994) they can involve protein-protein interactions either with accessory proteins or with proteins binding to closely adjacent or overlapping binding sites.

We extend these observations now in two aspects: first, we show that the distance from the start site of transcription can be a critical factor of discrimination. Although Myc was capable of activating from a distal enhancer position, USF was not, providing a simple explanation for the biological difference of both proteins. Indeed, most functional USF-binding sites that have been identified are in the vicinity of the start site of transcription (e.g., Meier et al. 1994; Timchenko et al. 1995). Similarly, a number of transcription factors have been shown to be specific activators from promoterproximal positions but largely inactive at enhancer positions (Seipel et al. 1992). Indeed, proteins of the Oct-2 family of transcription factors contain two activating domains, only one of which is capable of activating from an enhancer position (Annweiler et al. 1994). Our data show that Myc belongs to a class of transcription factors capable of activating from distal enhancer positions, and also suggests that some critical target genes of Myc have E-boxes in enhancer positions (see below).

Second, our data show that a distinct mechanism exists that discriminates against trans-activation of prothymosin- $\alpha$ by TFE-3. This appears to be related to a mechanism used in the B-cell-specific IgH enhancer to discriminate against trans-activation by $\mathrm{MyoD}$, a muscle-specific transcription factor, and against trans-activation by TFE-3 in non-B-cells (Genetta et al. 1994; Weintraub et al. 1994). The similarity extends to the findings that (1) in both cases a second E-box element is involved (Ruezinsky et al. 1991) and (2) that this E-box binds a putative repressor protein that discriminates against trans-activation by some, but not all E-box-binding proteins (Genetta et al. 1994). These data further support the notion that enhancer elements containing multiple E-box elements may constitute specific targets of individual E-box binding proteins. However, the sequence of the $\mu \mathrm{E} 5$-repressor element and the specificitydetermining element in the prothymosin- $\alpha$ intron are different and, based on the functional analysis of mutants at both sites, they appear to have different binding specificities for their putative repressor proteins (Weintraub et al. 1994; Fig. 4B). In addition, gel-shift experiments using a repressor protein (ZEB), which recognizes the $\mu \mathrm{E} 5$ element (Genetta et al. 1994), suggest that this protein is not involved in repression at the prothymosin- $\alpha$ intron enhancer (P. Staller, L. Desbarats, and M. Eilers, unpubl.).

Previously, a number of studies have analyzed domains of Myc required in trans-activating and transformation assays. These studies have shown that all mutations that impair the ability of Myc to bind to DNA and to heterodimerize with Max abolish or impair both the ability to trans-activate through E-box elements and the ability to induce cell transformation, proliferation, and apoptosis (Stone et al. 1987; Amati et al. 1992; Amati et al. 1993a|. Also, large deletions in the amino terminus of
Myc impair both transformation and trans-activation. However, smaller mutations often had marginal effects on trans-activation and, in many cases, this did not correlate with the biological effects of these mutations (Stone et al. 1987; Gaubatz et al. 1994; Philipp et al. 1994). In particular, mutations in Myc box II have been shown to enhance trans-activation of synthetic reporter construct by Myc, and at the same time, abolishing biological effects of the gene (Brough et al. 1995).

We now show that this is the result of the particular reporter construct used in these assays, and that, when assayed on a natural target gene of Myc, mutations in both Myc box I and, even more strongly, in Myc box II impair the ability of Myc to trans-activate from this site. Our data suggest that the critical difference between this study and the previous ones is the distance between the E-box and the start site of transcription in the reporters. The data here also reflect the differences in biological effects between mutations in Myc box I and II, as mutations in Myc box I affect transformation and trans-activation of prothymosin- $\alpha$ only moderately, whereas effects of mutations in box II are much more severe (Stone et al. 1987).

These findings reconcile data obtained from transient trans-activation experiments with those obtained in transformation assays, and further support a model in which E-box-dependent trans-activation is central to transformation by Myc. They do not rule out that other properties of Myc, like its ability to repress genes, contribute to transformation by Myc (Li et al. 1994; Philipp et al. 1994). However, one of the arguments to invoke gene repression as being important in transformation by Myc is the discrepancy between transformation and trans-activation assays with respect to mutations in $\mathrm{Myc}$ box II, and this has to be reevaluated in light of the finding that Myc box II contributes to gene activation by Myc.

One of the most puzzling findings of previous transactivation assays was the almost complete lack of synergy between Myc and Max proteins. We show here that, although synergy does not occur on proximal E-boxes, Myc and Max do synergize to trans-activate the prothymosin- $\alpha$ reporter. This is in agreement with the synergy observed for Myc and Max in transformation (Prendergast et al. 1992). It is still unclear why Myc and Max only synergize to activate from distal sites and not from proximal sites. One potential solution would be to suggest that Myc heterodimerizes through its HLH/LZ domains with proteins other than Max to activate from proximal positions; however, there is no evidence to support this notion. A second solution would be to suggest that significantly higher concentrations of functional Myc/Max heterodimers are required to activate from a distal than a proximal position; this way, endogenous levels of Max protein might be sufficient to support activation from a proximal, but not a distal, position. Some indication that this may be the case comes from observations that maximal activation is achieved with lower amounts of Myc expression plasmids from a proximal rather than from a distal position (L. Desbarats, unpubl.). In contrast to 
transformation assays, we observed little to no inhibition of Myc-mediated trans-activation by high concentrations of Max expression plasmids; biochemically, this might reflect the higher affinity of Max in forming heterodimers with Myc rather than homodimers. We suggest, therefore, that the apparent inhibition of focus formation observed with high concentrations of Max (Prendergast et al. 1992) may be attributable to increased apoptosis and not to inhibition of transformation, and thus, may reflect increased, rather than decreased, transactivation of target genes in the transformed cells.

Taken together, the data imply that target genes of Myc contain an E-box at a distal enhancer position, with a second "specificity-determining" E-box in close proximity. For a number of reasons, these data do not rule out that $\mathrm{E}$-boxes in promoter-proximal positions or lacking a $\mu E 5$-like element are also physiologically important targets of Myc. First, the data demonstrate only formally that a single target gene that is critically important for biological activities of Myc is similar to prothymosin- $\alpha$ regarding the requirement for Myc box II and the discrimination between Myc and other E-box-binding factors. This target gene may or may not be prothymosin- $\alpha$. Prothymosin- $\alpha$ encodes an acidic nuclear phosphoprotein that is essential for cell proliferation (Sburlati et al. 1991|. Prothymosin has been reported to interact with both histone H1 (Papamarcaki and Tsolas 1994) and with nuclear export signals (Kubota et al. 1995); thus, it might have regulatory functions in chromatin assembly or nuclear transport, or both. However, as the biochemical function of the protein is not known, it is hard to judge whether the prothymosin- $\alpha$ gene itself is a critical target for transformation by Myc.

Second, other mechanisms are easily conceivable that might make E-boxes specific for Myc. For example, two E-boxes that are target sites of Myc are found in close proximity in the first intron of the ornithine decarboxylase gene and both are required for trans-activation by Myc (Bello-Fernandez et al. 1993). Indeed, expression of ornithine decarboxylase is strongly induced in response to activation of conditional alleles of Myc (Wagner et al. 1993; G. Packham, J. Cleveland, B. Rudolph, and M. Eilers, unpubl.l. If Myc/Max complexes bound to such E-boxes synergistically but other transcription factors did not, such cooperating E-boxes might be sensitive to expression levels of Myc even if other E-box-binding factors are also able to activate from this site. Also, in the CAD gene, an E-box that is a potential target site of Myc is localized in close proximity to an E2F site and interactions between neighboring transcription factors might contribute to specificity (Miltenberger et al. 1995). Third, Myc binds a number of different E-box-like sequences and binding to noncanonical sequences might contribute to specificity (Blackwell et al. 1993).

However, we would predict that at least some target genes of Myc that are critically involved in the regulation of cell cycle, apoptosis, and transformation, share with prothymosin- $\alpha$ the requirement for Myc box II, synergy in trans-activation with Max, and the discrimination against other E-box-binding proteins, and therefore, might have similar response elements. We suggest, therefore, that our findings can be used as criteria to define such critical target genes of Myc.

\section{Materials and methods}

\section{Plasmids}

The plasmid PrT-CAT was constructed by first ligating a $2.8-\mathrm{kb}$ $H i n d I I I-X b a I$ fragment from the rat prothymosin- $\alpha$ gene /encompassing the first exon, first intron, and the first $8 \mathrm{bp}$ of the second exon) into pBLCAT6 digested with HindIII and $\mathrm{XbaI}$, followed by insertion of a 250-bp HindIII fragment containing the promoter of prothymosin- $\alpha$. To create GALmE-PrT-CAT, a fragment containing two GAL4-binding sites, obtained by digestion of the vector $17 \mathrm{~m}_{2}$-TATA-LUC (Annweiler et al. 1994) with HindIII and BamHI, and filling in of the ends with Klenow enzyme, was inserted into PrT-CAT digested with PmaCI (which disrupts the E-box). GAL4-TFE-3 was obtained by insertion of a 380-bp EcoRI-BglII fragment (coding for amino acids 1-126 of TFE-3) from the vector pSV2A- $\lambda 3$ (Beckmann et al. $1990)$ into the $5^{\prime}-E c o R I$ site and the BamHI site of pSG424 (Sadowski and Ptashne 1989). For GAL4-USF, PCR was used to amplify the first 543 bp (amino acids 1-181) of USF (5'primer: 5'-GGGAATTCATGAAGGGGCAGCAGAAA-3' and 3'-primer: 5'-GGGAATTCCTAGGGGCAATTGAGCG-3'); the amplified fragment was digested with EcoRI, then cloned into the EcoRI sites of pSG424. A plasmid encoding a histidinetagged TFE-3 protein was obtained by insertion of a $2.1-\mathrm{kb}$ BgIII-SmaI fragment (coding for amino acids 125-536 of TFE-3) from pSV2A- $\lambda 3$ (Beckmann et al. 1990) into pRSET-A, which was digested with EcoRI, filled in with Klenow enzyme, then digested with $B g I I I$. To obtain a plasmid expressing a fusion protein of the GAL4 DNA-binding domain and Myc box I, PCR was used to amplify the fragment corresponding to amino acids 44-65 of human c-Myc 15' primer: GAAGATCTGCGCCCAGCGAGGATATC; $3^{\prime}$ primer: CGGGATCCGCGGCTAGGGGACAGGGG). Two copies of the amplified fragment were cloned into pGBT10 and the GAL-Myc box I fragment was subcloned into the cytomegalovirus (CMV) expression plasmid pUHD. A plasmid for the expression of a GAL-Myc box II fusion protein was constructed by inserting two copies of an oligonucleotide corresponding to amino acids 129-144 of human c-Myc into pGBT10 and subcloning the GAL-Myc box II fragment into pUHD. CMV-TFE-3 was made by digestion of pSV2A- $\lambda 3$ with SmaI and EcoRI (partial) and insertion of the $2.5-\mathrm{kb}$ fragment into pUHD digested with SmaI and EcoRI. CMV-TFE- $3-\Delta$ C contains amino acids $1-233$ of TFE- 3 and was made by amplifying a 700-bp fragment from pSV2A- $\lambda 3$ (5'primer: 5 '-GGTCTAGAGAATTCGGGCGGGCTTCCCAG-3' and 3 '-primer: 5'-GGTCTAGATCATGGCAGGCCATGGA-TCTGGGCCTG-3'), which was digested with $X b a \mathrm{I}$ and cloned into the Xbal site of pUHD. The plasmids 36E-tkLUC, BbsMlu-tkLUC, Bbs-Xho-tkLUC (Gaubatz et al. 1994), and GAL4-Myc (Gaubatz et al. 1995) have been described previously. The mut1, mut2, mut4 (described in Gaubatz et al. 1995) mut 0 and dell oligonucleotides were inserted into the SmaI site of ptk81LUC. The mut 7 oligonucleotide $\left(5^{\prime}\right.$-AGCTTCGAGCACGTGGCCTGGGGCGCCAAGTGTACA-3') was inserted into the HindIII site of ptk81LUC. CMV-Myc and CMV-Myc with deletions in the amino terminus have been described (Philipp et al. 1994). CMV-Max, CMV-Max $\Delta$ LZ, and CMV-MaxmutRR (Prendergast et al. 1991), CMV-USF (Du et al. 1993), and murine CMV-Myc and mutants (Brough et al. 1995) have also been described previously. 


\section{Cell culture and transient transfection experiments}

HeLa cells were maintained in phenol red-free Dulbecco's modified Eagle medium plus $10 \%$ fetal bovine serum. For transient transfections, $2 \times 10^{5}$ to $5 \times 10^{5}$ cells were plated onto $6-\mathrm{cm}$ dishes, and refed $2 \mathrm{hr}$ before transfection. Transfections were performed using a standard calcium phosphate protocol (Sambrook et al. 1989). Unless otherwise indicated, reactions contained (1) effector plasmids driven either by a CMV promoter ( 1 $\mu \mathrm{g}$ ) or the SV40 promoter (10 $\mu \mathrm{g}$ pSV2A- $\lambda 3$ or $5 \mu \mathrm{g}$ GAL-fusion proteins), (2) reporter plasmids containing either the CAT (10 $\mu \mathrm{g})$ or luciferase $(5 \mu \mathrm{g})$ coding regions, and (3) $0.5 \mu \mathrm{g}$ of RSV- $\beta$ galactosidase. Cells were refed $18-24 \mathrm{hr}$ post-transfection, and harvested the following day. Luciferase and $\beta$-galactosidase assays were performed as described (Gaubatz et al. 1994), and CAT assays were carried out using a scintillation diffusion assay. The amount of acetylated ${ }^{14} \mathrm{C}$-labeled chloramphenicol was determined by scintillation counting after $1-4 \mathrm{hr}$ depending on the activity. CAT activity was calculated by subtracting the counts per minute value obtained at time zero and the endogenous CAT activity that was obtained by a mock transfection containing all plasmids except the reporter plasmid and calculated in the same way. Experiments were done in triplicate and repeated at least twice.

\section{Gel-shift experiments}

Myc/Max and USF gel-shift experiments were performed essentially as described in Gaubatz et al. (1995). Histidine-tagged Myc and Max proteins, expressed in and purified from bacteria, were preincubated at $30^{\circ} \mathrm{C}$ for $15 \mathrm{~min}$ before addition to the reaction (Gaubatz et al. 1995). Reactions contained $50 \mathrm{~mm}$ HEPES (pH $7.91,6 \mathrm{mM} \mathrm{MgCl} 2,50 \mathrm{mM} \mathrm{KCl}, 2.5 \mathrm{~mm} \mathrm{DDT}, 0.1 \mathrm{mg} / \mathrm{ml}$ of BSA, $0.5 \mu \mathrm{g}$ of poly [d(A-T)], $0.1 \%$ NP- $40,1 \times 10^{4} \mathrm{cpm}$ radiolabeled $36 \mathrm{E}$ oligonucleotide, and proteins and specific oligonucleotide competitors as described in figure legends. Gels were electrophoresed at $4^{\circ} \mathrm{C}$ in $0.5 \times \mathrm{TBE}, 0.01 \%$ NP- 40 . TFE- 3 gel-shift experiments were similar, except reactions contained $1 \mu \mathrm{g}$ of poly [d(I-C)] instead of poly [d(A-T)] and $0.5 \mu$ l of histidine-tagged TFE-3 protein purified from bacteria.

\section{Acknowledgments}

We thank Thomas Wirth, George Prendergast, Bernhard Lüscher, Günther Schütz, Bruno Amati, and Michael Cole for plasmids and Annette Ruppert for excellent technical assistance. This work was supported by the Deutsche Forschungsgemeinschaft (DFG) through the Sonderforschungsbereich 229 (SFB 229) and the Human Frontiers of Science Organization.

The publication costs of this article were defrayed in part by payment of page charges. This article must therefore be hereby marked "advertisement" in accordance with 18 USC section 1734 solely to indicate this fact.

\section{References}

Alitalo, K., J.M. Bishop, D.H. Smith, E.Y. Chen, W.W. Colby, and A.D. Levinson. 1983. Nucleotide sequence of the v-myc oncogene of avian retrovirus MC29. Proc. Natl. Acad. Sci. 80: 100-104.

Amati, B. and H. Land. 1994. Myc-Max-Mad: A transcription factor network controlling cell cycle progression. Curr. Opin. Genet. Dev. 4: 102-108.

Amati, B., S. Dalton, M.W. Brooks, T.D. Littlewood, G.I. Evan, and H. Land. 1992. Transcriptional activation by the human c-Myc oncoprotein in yeast requires interaction with Max
Nature 359: 423-426.

Amati, B., M.W. Brooks, N. Levy, T.D. Littlewood, G.I. Evan, and H. Land. 1993a. Oncogenic activity of the c-Myc protein requires dimerization with Max. Cell 72: 233-245.

Amati, B., T.D. Littlewood, G.I. Evan, and H. Land. 1993b. The $\mathrm{c}-\mathrm{Myc}$ protein induces cell cycle progression and apoptosis through dimerization with Max. EMBO J. 13: 5083-5087.

Amin, C., A.J. Wagner, and N. Hay. 1993. Sequence-specific transcriptional activation by Myc and repression by Max. Mol. Cell. Biol. 13: 383-390.

Annweiler, A., S. Zwilling, and T. Wirth. 1994. Functional difference between the Oct 2 transactivation domains deter mine the transactivation potential of individual Oct2 isoforms. Nucleic Acids Res. 22: 4250-4258.

Artandi, S.E., K. Merrell, N. Avitahl, K.-K. Wong, and K. Calame. 1995. TFE3 contains two activation domains, one acidic and the other proline-rich, that synergistically activate transcription. Nucleic Acids Res. 23: 3865-3871.

Ayer, D.E., L. Kretzner, and R.N. Eisenman. 1993. Mad: A heterodimeric partner for Max that antagonizes Myc transcriptional activity. Cell 72: 211-222.

Ayer, D.E., Q.A. Lawrence, and R.N. Eisenman. 1995. Mad-Myc transcriptional repression is mediated by ternary complex formation with mammalian homologs of yeast repressor Sin3. Cell 80: 767-776.

Beckmann, H., L.-K. Suo, and T. Kadesh. 1990. TFE3: A helixloop-helix protein that activates transcription through the immunoglobulin enhancer $\mu \mathrm{E} 3$ motif. Genes \& Dev. 4: 167179.

Beijersbergen, R.L., E.M. Hijmans, L. Zhu, and R. Bernards. 1994. Interaction of $\mathrm{c}-\mathrm{Myc}$ with the pRb-related protein $\mathrm{pl} 07$ results in inhibition of c-Myc-mediated transactivation. EMBO I. 13: 4080-4086.

Bello-Fernandez, C., G. Packham, and J.L. Cleveland. 1993. The ornithine decarboxylase gene is a transcriptional target of c-MYC. Proc. Natl. Acad. Sci. 90: 7804-7808.

Blackwell, T.K., L. Kretzner, E.M. Blackwood, R.N. Eisenman, and H. Weintraub. 1990. Sequence-specific DNA binding by the c-myc protein. Science 250: 1149-1151.

Blackwell, T.K., J. Huang, A. Ma, L. Kretzner, F.W. Alt, R.N. Eisenman, and H. Weintraub. 1993. Binding of Myc proteins to canonical and noncanonical DNA sequences. Mol. Cell. Biol. 13: 5216-5224.

Blackwood, E.M. and R.N. Eisenman. 1991. Max: A helix-loophelix zipper protein that forms a sequence-specific DNAbinding complex with myc. Science 251: 1211-1217.

Brough, D.E., T.J. Hofmann, K.B. Ellwood, R.A. Townley, and M.D. Cole. 1995. An essential domain of the c-myc protein interacts with a nuclear factor that is also required for E1Amediated transformation. Mol. Cell. Biol. 15: 1536-1544.

Chodosh, L.A., R.W. Carthew, and P.A. Sharp. 1986. A single polypeptide possesses the binding and transcription activities of the adenovirus major late transcription factor. Mol. Cell. Biol. 6: 4723-4733.

Cleary, M.A., S. Stern, M. Tanaka, and W. Herr. 1993. Differential positive control by Oct-1 and Oct-2: Activation of a transcriptionally silent motif through Oct-1 and VP16 corecruitment. Genes. \& Dev. 7: 72-83.

Colby, W.W., E.Y. Chen, D.H. Smith, and A.D. Levinson. 1983. Identification and nucleotide sequence of a human locus homologous to the $\mathrm{v}-m y c$ oncogene of avian myelocytomatosis virus MC29. Nature 301: 722-725.

Cziepluch, C., A. Wenzel, J. Schürmann, and M. Schwab. 1993. Activation of gene transcription by the amino terminus of $\mathrm{N}$-Myc does not require association with the protein encoded by the retinoblastoma gene RB1. Oncogene 8: 2833- 
2838.

Diamond, M.I., J.N. Miner, S.K. Yoshinaga, and K.R. Yamamoto. 1990. Transcription factor interactions: Selectors of positive or negative regulation from a single DNA element. Science 249: 1266-1272.

Du, H., A.L. Roy, and R.G. Roeder. 1993. Human transcription factor USF stimulates transcription through the initiator elements of the HIV-1 and the Ad-ML promoters. EMBO $J$. 12: $501-511$.

Eilers, M., D. Picard, K. Yamamoto, and J.M. Bishop. 1989. Chimaeras between the MYC oncoprotein and steroid receptors cause hormone-dependent transformation of cells. Nature 340: $66-68$.

Eilers, M., S. Schirm, and J.M. Bishop. 1991. The MYC protein activates transcription of the alpha-prothymosin gene. EMBO J. 10: 133-141.

Gaubatz, S., A. Meichle, and M. Eilers. 1994. An E-box element localized in the first intron mediates regulation of the prothymosin $\alpha$ gene by c-myc. Mol. Cell. Biol. 14: 3853-3862.

Gaubatz, S., A. Imhof, R. Dosch, O. Werner, P. Mitchell, R. Buettner, and M. Eilers. 1995. Transcriptional activation by $\mathrm{Myc}$ is under negative control by the transcription factor AP-2. EMBO J. 14: 1508-1529.

Genetta, T., D. Ruezinsky, and T. Kadesch. 1994. Displacement of an E-box-binding repressor by basic helix-loop-helix proteins: Implications for B-cell specificity of the immunoglobulin heavy-chain enhancer. Mol. Cell. Biol. 14: 6153-6163.

Gregor, P.D., M. Sawadogo, and R.G. Roeder. 1990. The adenovirus major late transcription factor USF is a member of the helix-loop-helix group of regulatory proteins and binds to DNA as a dimer. Genes \& Dev. 4: 1730-1740.

Gu, W., K. Bhatia, I.T. Magrath, C.V. Dang, and R. Dalla-Favera. 1994. Binding and suppression of the Myc transcriptional activation domain by pl07. Science 264: 251-254.

Hurlin, P.J., C. Quéva, P.J. Koskinen, E. Steingrimsson, D.E. Ayer, N.G. Copeland, N.A. Jenkins, and R. Eisenman. 1995. Mad3 and Mad4: Novel Max-interacting transcriptional repressors that supress c-myc dependent transformation and are expressed during neural and epidermal differentiation. EMBO J. 14: 5646-5659

Kakidani, H. and M. Ptashne. 1988. Gal4 activates gene expression in mammalian cells. Cell 52: 161-167.

Kerkhoff, E., K. Bister, and K.-H. Klempnauer. 1991. Sequencespecific DNA-binding by Myc proteins. Proc. Natl. Acad. Sci. 88: 4323-4327.

Kretzner, L., E.M. Blackwood, and R.N. Eisenmann. 1992. Myc and Max proteins possess distinct transcriptional activities. Nature 359: 426-429.

Kubota, S., Y. Adachi, T.D. Copeland, and S. Oroszlan. 1995. Binding of human prothymosin alpha to the leucine-motif/ activation domains of HTLV-1 Rex and HIV-1 Rev. Eur. I. Biochem. 233: 48-54.

Lai, J.S., M.A. Cleary, and W. Herr. 1992. A single amino acid exchange transfers VP16-induced positive control from the Oct-1 to the Oct-2 homeo domain. Genes \& Dev. 6: 20582065.

Landschulz, W.H., P.F. Johnson, and S.L. McKnight. 1988. The leucine zipper: A hypothetical structure common to a new class of DNA binding proteins. Science 240: 1759-1764.

Lee, L.A., L.M. Resar, and C.V. Dang. 1995. Cell density and paradoxical transcriptional properties of $\mathrm{c}-\mathrm{Myc}$ and Max in cultured mouse fibroblasts. J. Clin. Invest. 95: 900-904.

Li, L., C. Nerlov, G. Prendergast, D. MacGregor, and E.B. Ziff. 1994. c-Myc represses transcription in vivo by a novel mechanism dependent on the initiator element and Myc box II. EMBO \%. 13: 4070-4079.
Littlewood, T.D., B. Amati, H. Land, and G.I. Evan. 1992. Max and c-Myc/Max DNA-binding activities in cell extracts. Oncogene 7: 1783-1792.

Meier, J.L., X. Luo, M. Sawadogo, and S.E. Straus. 1994. The cellular transcription factor USF cooperates with varicellazoster virus immediate-early protein 62 to symmetrically activate a bidirectional viral promoter. Mol. Cell. Biol. 14: 6896-6906.

Miltenberger, R.J., K.A. Sukow, and P.J. Farnham. 1995. An E-box-mediated increase in cad transcription at the G(1)/Sphase boundary is suppressed by inhibitory c-Myc mutants. Mol. Cell. Biol. 15: 2527-2535.

Murre, C., P. Schonleber-McCaw, and D. Baltimore. 1989. A new DNA binding and dimerization motif in immunoglobulin enhancer binding, daughterless, MyoD, and myc proteins. Cell 56: 777-783.

Papamarcaki, T. and O. Tsolas. 1994. Prothymosin alpha binds to histone $\mathrm{Hl}$ in vitro. FEBS Lett. 345: 71-75.

Philipp, A., A. Schneider, I. Väsrik, K. Finke, Y. Xiong, D. Beach, K. Alitalo, and M. Eilers. 1994. Repression of cyclin D1: A novel function of MYC. Mol. Cell. Biol. 14: 4032-4043.

Prendergast, G.C. and E.B. Ziff. 1991. Methylation-sensitive sequence-specific DNA binding by the c-myc basic region. Science 251: 186-189.

Prendergast, G.C., D. Lawe, and E.B. Ziff. 1991. Association of myn, the murine homolog of max, with c-myc stimulates methylation-sensitive DNA binding and ras cotransformation. Cell 65: 395-407.

Prendergast, G.C., R. Hopewell, B.J. Gorham, and E.B. Ziff. 1992. Biphasic effect of Max on Myc contransformation activity and dependence on amino- and carboxy-terminal Max functions. Genes \& Dev. 6: 2429-2439.

Roy, A.L., C. Carruthers, T. Gutjahr, and R.G. Roeder. 1993. Direct role for Myc in transcription initiation mediated by interactions with TFII-I. Nature 365: 359-361.

Ruezinsky, D., H. Beckmann, and T. Kadesch. 1991. Modulation of the IgH enhancer's cell type specificity through a genetic switch. Genes \& Dev. 5: 29-37.

Sadowski, I. and M. Ptashne. 1989. A vector for expressing GAL4(1-147) fusions in mammalian cells. Nucleic Acids Res. 17: 7539.

Sambrook, J., E.F. Fritsch, and T. Maniatis. 1989. Molecular cloning. Cold Spring Harbor Laboratory Press, Cold Spring Harbor, NY.

Sburlati, A.R., R.E. Manrow, and S.L. Berger. 1991. Prothymosin alpha antisense oligomers inhibit myeloma cell division. Proc. Natl. Acad. Sci. 88: 253-257.

Schreiber-Agus, N., L. Chin, K. Chen, R. Torres, G. Rao, P. Guida, A.I. Skoultchi, and R.A. DePinho. 1995. An aminoterminal domain of Mxil mediates anti-Myc oncogenic activity and interacts with a homolog of the yeast transcriptional repressor SIN1. Cell 80: 777-786.

Seipel, K., O. Georgiev, and W. Schaffner. 1992. Different activation domains stimulate transcription from remote ("enhancer") and proximal ("promoter") positions. EMBO $J$. 11: 4961-4968.

Stone, J., T. de Lange, G. Ramsay, E. Jakobovits, J.M. Bishop, H. Varmus, and B. Lee. 1987. Definition of regions in human c-myc that are involved in transformation and nuclear localization. Mol. Cell. Biol. 7: 1697-1709.

Tavtigian, S.V., S.D. Zabludoff, and B.J. Wold. 1994. Cloning of Mid- $G_{1}$ serum response genes and identification of a subset regulated by conditional myc expression. Mol. Biol. Cell 5: 375-388.

Timchenko, N., D.R. Wilson, L.R. Taylor, S. Abdelsayed, M. Wilde, M. Sawadogo, and G.J. Darlington. 1995. Autoregula- 


\section{Desbarats et al.}

tion of the human C/EBP alpha gene by stimulation of upstream stimulatory factor binding. Mol. Cell. Biol. 15: 11921202.

Wagner, A.J., C. Meyers, L.A. Laimins, and N. Hay. 1993. c-Myc induces the expression and activity of ornithine decarboxylase. Cell Growth Differ. 4: 879-883.

Watson, D.K., E.P. Reddy, P.H. Duesberg, and T.S. Papas. 1983. Nucleotide sequence analysis of the chicken c-myc gene reveals homologous and unique coding regions by comparison with the transforming gene of avian myelocytomatosis virus MC29, sgag-myc. Proc. Natl. Acad. Sci. 80: 2146-2150.

Weintraub, H., T. Genetta, and T. Kadesch. 1994. Tissue-specific gene activation by MyoD: Determination of specificity by cis-acting repression elements. Genes \& Dev. 8: 22032211.

Zervos, A.S., J. Gyuris, and R. Brent. 1993. Mxil, a protein that specifically interacts with Max to bind Myc-Max recognition sites. Cell 72: 223-232. 


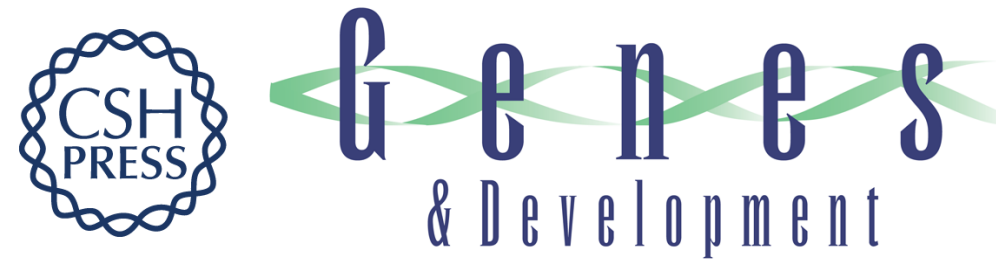

\section{Discrimination between different E-box-binding proteins at an endogenous target gene of c-myc.}

L Desbarats, S Gaubatz and M Eilers

Genes Dev. 1996, 10:

Access the most recent version at doi:10.1101/gad.10.4.447

References This article cites 61 articles, 31 of which can be accessed free at: http://genesdev.cshlp.org/content/10/4/447.full.html\#ref-list-1

License

Email Alerting

Service

Receive free email alerts when new articles cite this article - sign up in the box at the top right corner of the article or click here.

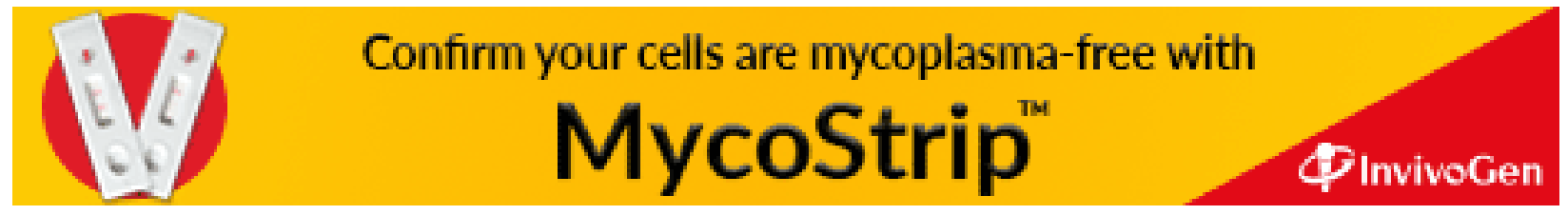

